\title{
Kawung: Landraces, management, uses, and conservation based on moral versus economic interest among Outer Baduy community, South Banten, Indonesia
}

\author{
BUDIAWATI SUPANGKAT ISKANDAR ${ }^{1, \bullet}$, JOHAN ISKANDAR ${ }^{2,3,4}$ \\ ${ }^{1}$ Department of Anthropology, Faculty of Social and Political Science, Universitas Padjadjaran. J1. Raya Bandung-Sumedang Km 21, Jatinangor, \\ Sumedang 45363, West Java, Indonesia. Tel./fax.: +62-22-7796416, `email: budiawati.supangkat@ unpad.ac.id \\ ${ }^{2}$ Department of Biology, Faculty of Mathematics and Natural Sciences, Universitas Padjadjaran. Jl. Raya Bandung-Sumedang Km 21, Jatinangor, \\ Sumedang 45363, West Java, Indonesia \\ ${ }^{3}$ Graduate Program of Environmental Science, Universitas Padjadjaran. Jl. Dipati Ukur, Bandung 4034, West Java, Indonesia \\ ${ }^{4}$ Center for Environment and Sustainability Science, Universitas Padjadjaran. Jl. Sekeloa Selatan 1, Bandung 4034, West Java, Indonesia
}

Manuscript received: 21 September 2021. Revision accepted: 27 November 2021.

\begin{abstract}
Iskandar BS, Iskandar J. 2021. Kawung: Landraces, management, uses, and conservation based on moral versus economic interest among Outer Baduy community, South Banten, Indonesia. Biodiversitas 22: 5572-5584. The sugar palm or kawung (Arenga pinnata (Wurm) Merr.) has naturally or semi naturally grown in many rural areas of Banten and West Java. The sugar palm has social, economic, cultural, and ecological benefits for rural communities, but its population has dramatically decreased. This study aimed to access the knowledge, traditional management, uses and traditional conservation of sugar palm. This research used a qualitative method with an ethnoecological approach. The results showed that the Outer Baduy community has a rich knowledge of sugar palm. Two landraces of sugar palm are recognized by Outer Baduy mainly kawung gedé and kawung salompét. They have not intensively cultivated the sugar palm, but managed the kawung seedlings which grow naturally or assisted by civet or careuh in traditional agroforestry systems, including huma, reuma, leuweung lembur, and leuweung kolot. The weeds growing surrounding the seedlings are cleared, and then the seedlings will grow naturally and finally develop to mature trees. The sugar palm has been traditionally used for ecological, socio-economic, and cultural functions. The Outer Baduy community has traditionally conserved the sugar palm which grows in traditional agroforestry systems. The sugar palm trees, fruits, and the stems have never been cut, used as the sweetmeats, and made into sago flour, respectively, while the civets which have assisted distribution and regeneration of the sugar palm have never been hunted, and their habitat has never been destroyed.
\end{abstract}

Keywords: Ethnoecology, kawung, Outer Baduy community, traditional ecological knowledge

\section{INTRODUCTION}

The sugar palm plant (Arenga pinnata (Wurmb) Merr.) is recognized as a native plant species to the Indo-Malayan archipelago, with its distribution center in Indonesia (Mogea et al. 1991). Since Indonesia has been the center of the sugar palm distribution, this plant can be found widely in many rural areas in Indonesia, including Java, Madura, Bali, Nusa Tenggara, Sumatra, Kalimantan, Sulawesi and Papua. This sugar plant has various local names in various ethnic groups in Indonesia, such as kawung (Sunda), aren (Jawa, Madura), hano (Bali), pola (Sumbawa), kalotu (Sumba), nao (Bima), maoke (Flores), nau (Timor), hanau (Kerinci), poula (Mentawai), peto (Nias), bargot (Mandailing), ijuk (Gayo), pola or paula (Karo), bagot or agaton (Toba), bak jug (Aceh), seho (Manado), and sageru (Maluku) (Kurniawan et al. 2018).

Among the plant species of the Arecaceae family, sugar palm (A. pinnata) is known as one of the multipurpose trees (MPTs) for the rural communities in Indonesia. Sugar palm provides social, economic and cultural benefits to rural communities in various parts of Indonesia, for example, the production of palm sugar, palm wine (tuak), sweetmeat (kolang kaling), palm flour (sagu), roof material, palm fiber brooms, stick brooms, cigarette paper, traditional medicine, botanical pesticide, and traditional ceremonial materials (Fatriani et al. 2012; Iskandar and Iskandar 2017; Amrul et al. 2018; Anwar 2018; Erawan et al. 2018; Azhar et al. 2019; Sujarwo et al. 2020; Iskandar 2021; Ratnani et al. 2021; Withaningsih et al. 2021).

Although sugar palm has many benefits for rural people in Indonesia, in general this plant has not been cultivated by the rural people. It grows naturally, and its regeneration in various rural ecosystems is mainly assisted by the common palm civet, careuh or luwak (Paradoxurus hermaphroditus Pallas, 1777) (Surya et al. 2018; Withaningsih et al. 2019; Zuhud et al. 2020) because the common palm civet, in addition to eating other animals, also loves eating various fruits, including Arabica coffee (Coffea arabica L.), kondang (Ficus variegata Blume), and sugar palm. Since the common palm civet has predominantly eaten the palm sugar palm fruits, the feces of this animal usually contains a lot of the sugar palm seeds that can potentially germinate and grow into seedlings of the sugar palm in nature (Subrata and Syahbudin 2016).

Like in other rural areas in Indonesia, sugar palm in many rural areas in Banten and West Java grows naturally or semi-naturally in various land uses, including 
homegardens, mixed-gardens, swidden farmings, and forests (Iskandar 2012; Febriyanti et al. 2017; Gunawan et al. 2018; Withaningsih et al. 2019). The population of sugar palm in rural areas of Banten and West Java is determined by inputs and outputs to stock of the sugar palm population. Inputs for population level of the palm sugar is determined predominantly by natural regeneration rate, while outputs is determined by natural death, exploitation rate, and conversion rate of land uses that are grown with sugar palm to other land use types. Because the exploitation of the sugar palm both for home industrial activities, including making palm sugar, sweetmeat and palm flour and intensive conversion of land uses having the sugar palm has rapidly increased and population of the common palm civet has decreased, the population of sugar palm is getting lower in rural ecosystems. In other words, the input rate is lower than the output rate. Moreover, the decreasing or even disappearance of the sugar palm in rural areas of Banten and West Java may cause the decreasing or disappearance of various functions of the sugar palm for rural people.

Unlike the Sundanese people in general, the traditional Baduy people who reside in Kanekes Village, Leuwidamar District, Lebak District, South Banten, have traditionally conserved the kawung in their village based on the Traditional Ecological Knowledge (TEK) strongly embedded with their culture. So, it can be seen that there is a strong relationship between cultural factors, such as local language, the TEK and the biodiversity conservation of the Baduy (Franco et al. 2015; Hidayati et al. 2017). Given the ecological and cultural importance of kawung, it may be considered as cultural keystone species of Baduy rural ecosystems (Garibaldi and Turner 2004; Ellen 2006; Platten and Henfrey 2009; Coe and Gaoue 2020).

The purpose of this study was to assess the knowledge of the Outer Baduy on kawung landraces, kawung management, various uses of kawung, and traditional kawung conservation.

\section{MATERIALS AND METHODS}

\section{Study area}

The study was undertaken in 3 hamlets of Outer Baduy, namely Kaduketug, Babakan Marengo, and Gajeboh, Kanekes Village, Leuwidamar Sub-district, Lebak District, Banten, West Java (Figure 1).

Baduy has a total area of about 5,136.58 hectares. About 3,000 hectares (58\%) of the land area is designated as protected forest, and approximately 2,136.58 hectares $(48 \%)$ as swidden field and secondary fallowed land, and settlement. The Baduy area has been established as customary land (tanah ulayat) by the local government of Lebak District, Banten since 2000 (Iskandar 2012).

Baduy area is located in village of Kanekes, sub-district of Leuwidamar, district of Lebak, province of Banten, Indonesia and resided by the Sundanese traditional people called Baduy people. Traditionally, Baduy can be divided into two areas: Inner Baduy (Baduy Jero or Baduy Dalam) and Outer Baduy (Baduy Luar or Baduy Panamping), which is based on village administrative.

Inner Baduy consists of 3 hamlets, namely Cibeo, Cikartawarna, and Cikeusik. Meanwhile, Outer Baduy consists of more than 60 hamlets, located predominantly in the northern part of Kanekes village which surrounds the Inner Baduy. Traditionally the Inner Baduy people hold custom or adat stronger than the Outer Baduy people. The Baduy informal leader, called Puun, consists of Puun Cibeo, Puun Cikartawarna, and Puun Cikeusik who resides in hamlet of Cibeo, Cikartawarna, and Cikeusik, respectively. The total population of Baduy in 2018 was 11,710 people, representing 3,414 households, consisting of about $83 \%$ of the Outer Baduy people, and only $17 \%$ of the Inner Baduy (Statistical Data of Kanekes Village 2018).

The Baduy people live mainly as swidden farmers (peladang or pahuma), but they have additional livelihoods. The women are mainly involved in weaving cloth, while the men make traditional knitted bags, jarog and koja, made from bark fibers of teureup (Artocarpus elasticus Reinw. ex Blume) (Figure 2), and, for outer Baduy people only, make palm sugar (gula kawung) by tapping peduncles of kawung because the Inner Baduy people are traditionally prohibited from making palm sugar.

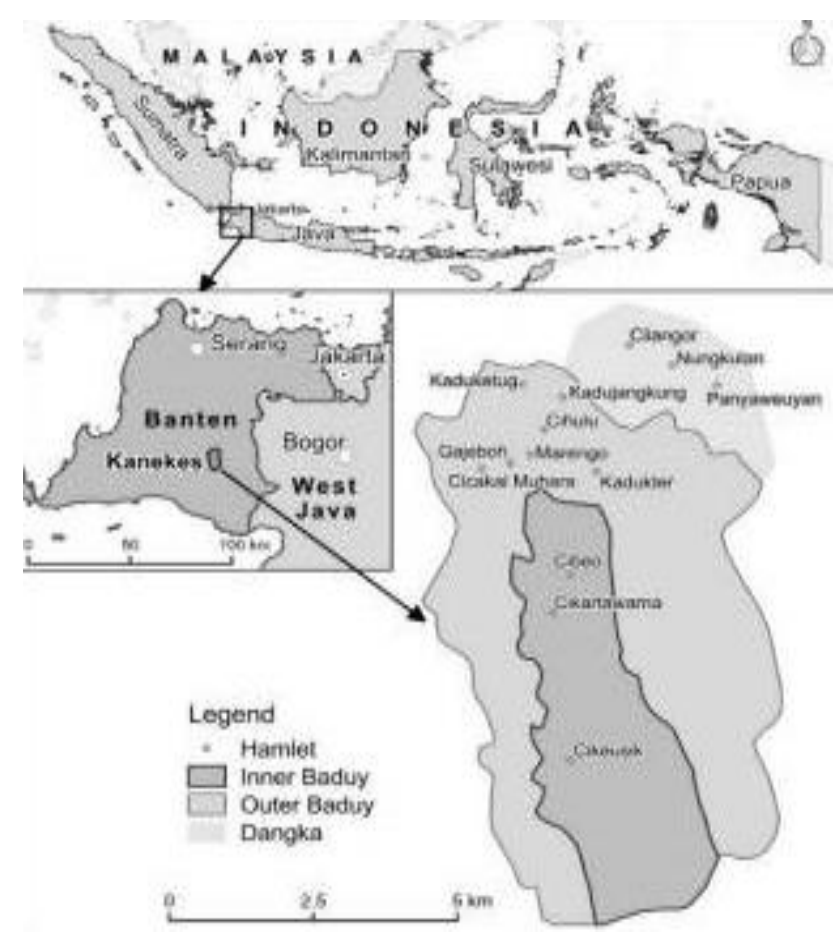

Figure 1. Study sites in hamlets of Kaduketug, Marengo, and Gajeboh, Outer Baduy, Kanekes Village, Leuwidamar Subdistrict, Lebak District, Banten Province, Indonesia (Adapted from Iskandar and Ellen 1999) 

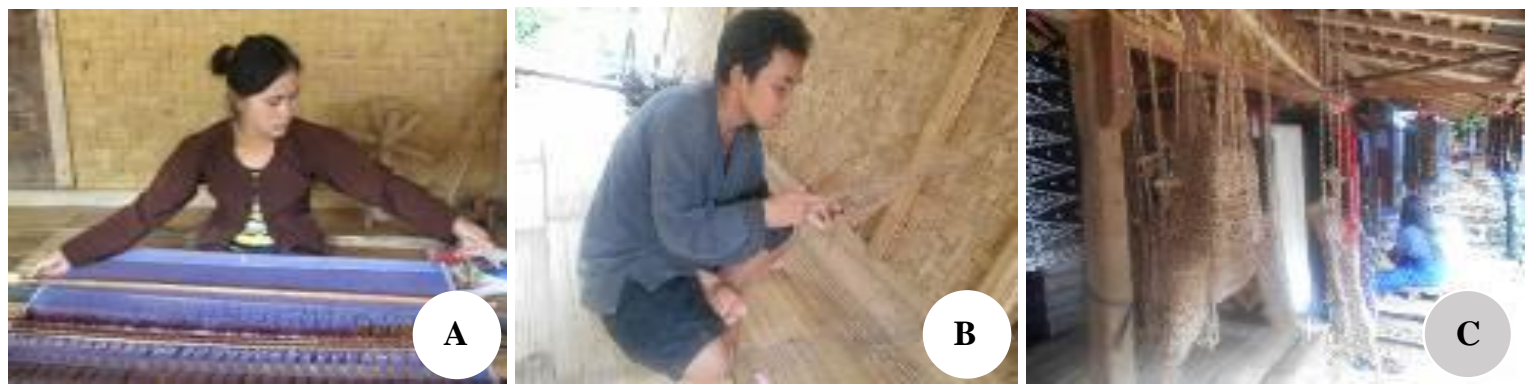

Figure 2. A. A woman is weaving cloth, B. A man is knitting traditional bag, and C. The traditional bags and the traditional woven cloths are being displayed in Outer Baduy house for trading to visitors who come to Baduy area

\section{Procedures}

The method used in this study was qualitative with the ethnoecological approach (Albuquerque et al. 2014). Some techniques, including observation, participant observation, and deep interview were employed to collect primary data (Newing et al. 2011; Albuquerque et al. 2014).

As the first step to any ethnobotanical or ethnobiological research, concerns seeking, rapport building, and ethical considerations are important. In accordance with requirement of ethics, we were careful to ensure the rights of individuals were not infringed upon. The research permit letter was obtained from the University of Padjadjaran and district of Lebak. At the beginning of the field study, we reported and asked permission for the research plan to the village leader and his staff at the house of formal village leader (Jaro Pamaentah) and at the same time looked for houses of the Outer Baduy that could be used as base camps during the field research. Three hamlets, namely Kaduketug, Babakan Marengo, and Gajeboh were chosen for study area because they are located quite close together and many Outer Baduy households in these hamlets own sugar palm trees and make palm sugar industries in their home. During our fieldwork, between 2015 and 2017, we undertook several field visits, and in each visit we stayed for about a week in the Outer Baduy home.

The field observation was carried out to observe the local environment, including the human settlement or hamlet, village forest (leuweung lembur), swidden field (huma), fallowed secondary forest (reuma), and protected mature forest (leuweung kolot). In addition, observation was done to observe informant activities, including tapping the peduncles of kawung, boiling the juice, molding sugar using wooden molds, and wrapping the palm sugar.

Participant observation was undertaken during which the researchers accompanied an informant both to observe what he did and said, and also participated in some activities, including going to swidden field to tap the peduncles of kawung, and going to the informant house to observe and participate in boiling the juice of kawung sugar, and so on. While the deep interviews were employed with informants that were purposely selected based on their competence with considering the diversity of informants. Total informants were 16 people, consisting of the village leader (Jaro Pemerintah), secretary of village leaders (Carik Desa), hamlet informal leaders (Kokolot Lembur), kawung owners, tapper and maker of kawung palm sugar, and village middlemen. They reside in Outer Baduy hamlets, including hamlets of Kaduketug, Babakan Marengo, and Gajeboh. In the deep interview with informants, the informants gave extensive responses to a series of general questions, some of which had been prepared in advance and some of which arose naturally during the conversation. Some aspects were intensively discussed with informants, namely kawung landraces, utilizations, and conservation of kawung.

\section{Data analysis}

Data were analyzed in some stages, including crosschecking, summarizing, synthesizing, and made narrative (Newing et al. 2011). The cross-checking was done to validate the data collected with observation, participant observation, and deep interview. The valid data were summarized and synthesized. Moreover, it was made narrative with descriptive and evaluative analysis.

Some literatures, including Backer et al. (1968) and Heyne (1987) were used to identify plant species that were used to make utensils, preservatives, and firewood to make the palm sugar. In addition, some plant species were identified in the plant taxonomic laboratory of the Department of Biology, Faculty of Mathematics and Natural Sciences, Universitas Padjadjaran, Sumedang, Indonesia.

\section{RESULTS AND DISCUSSION}

\section{Knowledge of Kawung landraces}

Based on botanical classification formulated by ethnobotanists, including Rapini (2014) and Iskandar (2018), the Outer Baduy community knows kawung very well in 4 level (Table 1).

At a level of unique beginner (level 0), the Outer Baduy people usually distinguish the terms for cultivated plant species which are commonly called pepelakan (crops) and species of wild plants called tutuwuhan (plants). However, since the kawung is not specially planted in various land use types of Outer Baduy, this plant is considered plants (tutuwuhan) instead of crop (pepelakan). 
Table 1. Folk botanical classification of kawung based on Outer Baduy community

\begin{tabular}{|c|c|c|c|c|}
\hline \multirow{2}{*}{ Level } & \multicolumn{3}{|c|}{ Class } & \multirow{2}{*}{ Rank } \\
\hline & Baduy term & Indonesian term & English term & \\
\hline 0 & Tutuwuhan & Tumbuh-tumbuhan & Plant & Unique beginner \\
\hline 1 & Tangkal/Kakayon*) & Pohon & Tree & Life form \\
\hline 2 & Kawung & Aren & Sugar palm & Generic/species \\
\hline 3 & Kawung gedé & Kawung besar & Big sugar palm & Varietal \\
\hline 4 & Kawung salompét & Kawung kecil/Salompét & Little palm sugar & \\
\hline
\end{tabular}

Note: *In Sundanese of non-Baduy, tangkal can also called palem tree

Table 2. Outer Baduy vocabulary of kawung (Arenga pinnata) partonyms

\begin{tabular}{lll}
\hline Baduy term & Indonesian term & English term \\
\hline Leaves: & & \\
Daun & Daun & Leaf \\
Pucuk daun kawung & Pucuk daun aren & Young leaf of kawung palm \\
Daun kawung & Daun aren & Leaf of kawung palm \\
Palapah daun & Pelepah daun & Leaf midrib \\
Injuk & Ijuk & Fiber from leaf \\
& & \\
Reproductive parts: & & \\
Kembang kawung & Bunga aren & Flower of Sugar palm \\
Leungeun kembang (see Figure 3) & Tangkai bunga aren & Stalk on which fruit grow \\
-Gelap & -Tangkai bunga aren ke 1 dari atas & -First stalk from upper \\
-Adi gelap & -Tangkai bunga aren ke 2 dari atas & -Second stalk from upper \\
-Caruluk & -Tangkai bunga aren ke 3 dari atas & -Third stalk from upper \\
-Jenah & -Tangkai bunga aren ke 4 dari atas & -Forth stalk from upper \\
-Bulu kélék & -Tangkai bunga aren ke 5 dari atas & -Fifth stalk from upper \\
-Béngkél & -Tangkai bunga aren ke 6 dari atas & -Sixth stalk from upper \\
Caruluk & Buah aren & Fruit of sugar palm \\
Harupat/injuk aren & Ijuk aren & Black fiber \\
& & \\
Stem: & & Trunk \\
Tangkal & Pohon & Flour of trunk core \\
Sagu & Sagu, Tepung aren & \\
Roots: & & Roots \\
Akar & Akar &
\end{tabular}

At the life form level (level 1), based on the Outer Baduy community, plants can be divided into some types, including kakayon or tangkal (tree), jukut (grass), rungkun (bush), and areuy (vine). One example of tangkal or kakayon (tree) is 1 kawung, included at generic level (level 2 ). The Sundanese of non-Baduy recognize species of tangkal palem (Palmae trees), including kawung (A. pinnata), kawung monyét, saray or langkap (Caryota mitis Lour.), jambé or pinang (Areca catechu L.), and so on.

We use the word landrace which is applied by scholars, including Soemarwoto and Iskandar (2021) to distinguish local categories of kawung variations, based on knowledge of Outer Baduy people, with Western botanical sense. The landrace is different from the botanical scientific in that it is based on category for subdivision of ancestral plant varieties in the conventional Western taxonomic sense.

Based on Outer Baduy, kawung is categorized into two landraces at varietal level (level 3): kawung gedé (big kawung) and kawung salompét (small kawung). Kawung gedé has the following characteristics, namely having tall trunk, big trunk diameter, lot of fruit, and may be tapped producing lot of juice. Meanwhile, kawung salompét has the following characteristics: having short trunk, small trunk diameter, little fruit, and can be tapped producing little juice, but adapted to shaded place.

The Sundanese people of Cipanggulaan community of Karyamukti Village, Cianjur, West Java is similar to Outer Baduy community in that they divide kawung into two landraces, namely kawung cibuy and kawung alit or kawung saéran (Gunawan et al. 2018). However, Rancakalong Sundanese community of Rancakalong Village, Sumedang, West Java, is different from the Cipanggulaan and Outer Baduy. They divide kawung into 4 landraces: kawung ageung or kawung gedé, kawung kembang, and kawung monyét. Kawung ageung or kawung gedé has these characteristics: it has tall trunk, big trunk diameter, lot of fruits, can be tapped, and usually grows in open vegetation canopy. Kawung kembang has the following characteristics: it has tall trunk, big trunk diameter, little fruits, can be tapped or cannot be tapped, and is adapted to living under shading vegetation canopy. Kawung saéran has characteristics: having short trunk, 
small trunk diameter, moderate amount of fruit, can be tapped, and adapted to living under shading canopy. While kawung monyét has characteristics: short trunk, small trunk diameter, little amount of fruit, cannot be tapped, and adapted to living under shading canopy. Botanically, the three landraces, namely kawung angeung, kawung kembang, and kawung saéran are identified as A. pinnata (Wutmb) Merr.); however, kawung monyét is identified as C. mitis, family Arecaeae (Iskandar 2018).

Based on patronym that refers to the phenomenon of referring to part of a whole through specialized term (https://www.wordsense.eu/partonym/2 May 2021), the various parts of kawung are distinctively given names, including daun (leaf), injuk (fiber from leaf), tangkal (trunk), sagu (trunk core), kembang (flower), caruluk (fruit), and leungeun (stalk) (Table 1). Moreover, stalk itself can be divided into six different types, from upper to lowers in succession, namely gelap, adi gelap, caruluk, jenah, bulu kélék, and béngkél, respectively (Figure 3).

It can be seen from Table 2, Outer Baduy and Cipanggulaan community, Karyamukti village of Cianjur all have rather similar local terms of $A$. pinnata parthonyms, such as daun (leaf), kembang (flower), buah caruluk (fruit), leungeun (stalk), tangkal (trunk), and akar (root) (Gunawan et al. 2018).

In terms of stalk, however, Outer Baduy and Cipanunggalan community are dissimilar in that Baduy community has more terms than Cipanggulaan, Cianjur on stalk. The stalk of kawung can be divided by Baduy Community into different types, i.e., gelap, adi gelap, caruluk, jenah, bulu kélék, and caruluk (Figure 3).

\section{Traditional management of kawung}

Kawung grows naturally or semi-naturally in various agroforestry traditional of Outer Baduy, including huma, reuma, leuweung lembur, and leuweung kolot. Particularly, kawung trees are predominantly found in the huma agroforestry traditional systems. The initial kawung trees have predominantly been grown in huma as follows: at the time of the land preparation for swidden faming (huma), all undergrowth vegetation of mature secondary forest was cut down totally. Meanwhile, some economically-valuable perennial plants, including kadu/durian (Durio zibethinus L.), peuteuy/petai (Parkia speciosa Hassk.), jengkol (Archidendron pauciflorum (Benth.) I.C.Nielsen), mangga (Mangifera indica L.), kaweni (Mangifera odorata Griff.), kalapa (Cocos nucifera L.) and kawung (A. pinnata) are only pruned by cutting the branches and twigs, and left to grow mixed with paddy crop and other annual crops later in the huma system. For example, the kawung trees at the time of clearing of the mature secondary forest are not cut down, but only the midrib leaves are cut, leaving young leaves and stalk of kawung on which fruit grow.

All vegetation biomass cut is left to dry by sunlight. After drying, it is collected into several piles and burned to produce organic fertilizer. During the burning of the vegetation biomass, the kawung fruit that falls to the ground around the palm trees is also burned. Some of the kawung seeds, however, are burned without being damaged, even breaking the dormancy. At the start of the rainy season, the land that has been cleared is planted with the upland paddy crop (Oryza siva L.) and other annual crops, including hiris (Cajanus cajan (L.) Huth), kacang penyut (Vigna sinensis (L.) Savi ex Hassk.), dégéng (Setaria viridis (L.) P.Beauv.), hanjeli (Coix lacryma-jobi L), jagong (Zea mays L.), bonténg (Cucumis sativus L.), kumili (Coleus rotundifolius (Poir.) A.Chev. \& Perrot), tiwu (Saccharum officinarum L.), and cau (Musa $x$ paradisiaca $\mathrm{L}$.). When the paddy crop begins to grow, the remnants of the undamaged burned kawung seeds exposed and lost their dormancy also grow mixed with the paddy and other annual crops. In order to maintain the kawung seedlings, usually various terrestrial weeds, such as the grasses that grow around the palm seedlings, are removed. When the paddy crops are cleared of weeds, so are the sugar palm seedlings. As the paddy crops grow taller, kawung seedlings also grow taller, and the mature kawung, whose midrib was cut during the land clearing, can regrow. As a result, kawung trees grow dominantly on the huma land forming the Baduy huma agroforestry system (Figure 4). Furthermore, after the harvesting of paddy in huma, kawung are allowed to naturally grow in the fallowed secondary forest, which is reopened for swidden farming system after having been left fallow for more than 3 years. The procedure for cutting down vegetation of the mature secondary forest in preparing land for swidden farming is the same as previously narrated, namely that shrubs are cut down and perennial crops trees that have economic importance, including kawung, are pruned by cutting the leaf midrib only.

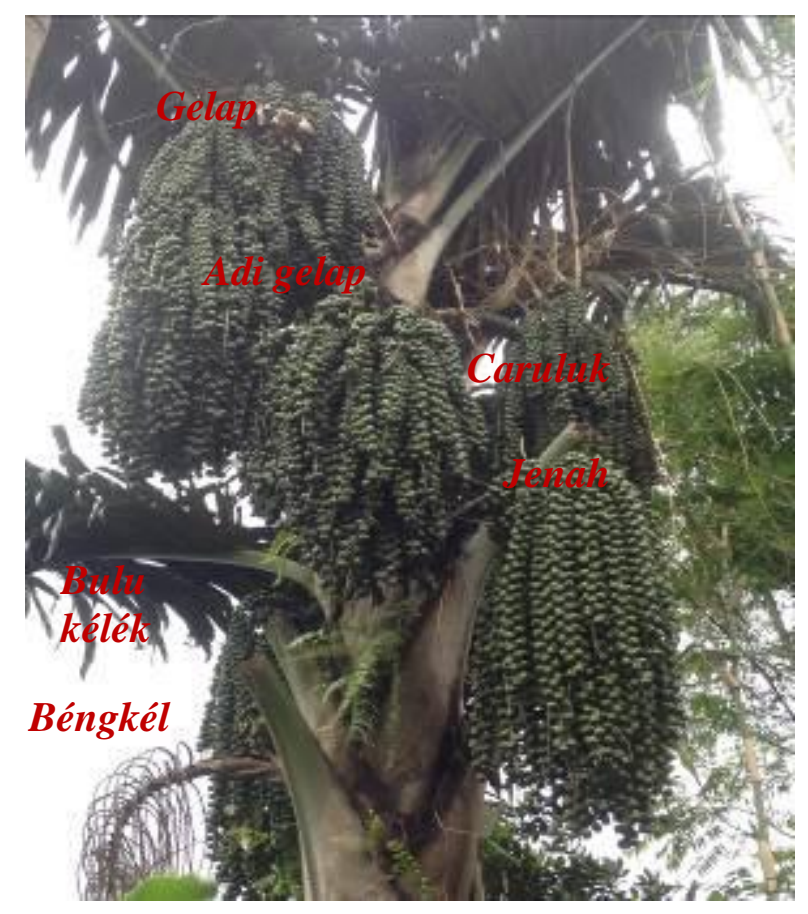

Figure 3. Stalk on which fruit grow can be divided into 6 types from up to bottom: gelap, adi gelap, caruluk, jenah, bulu kélék, and béngkél, respectively 


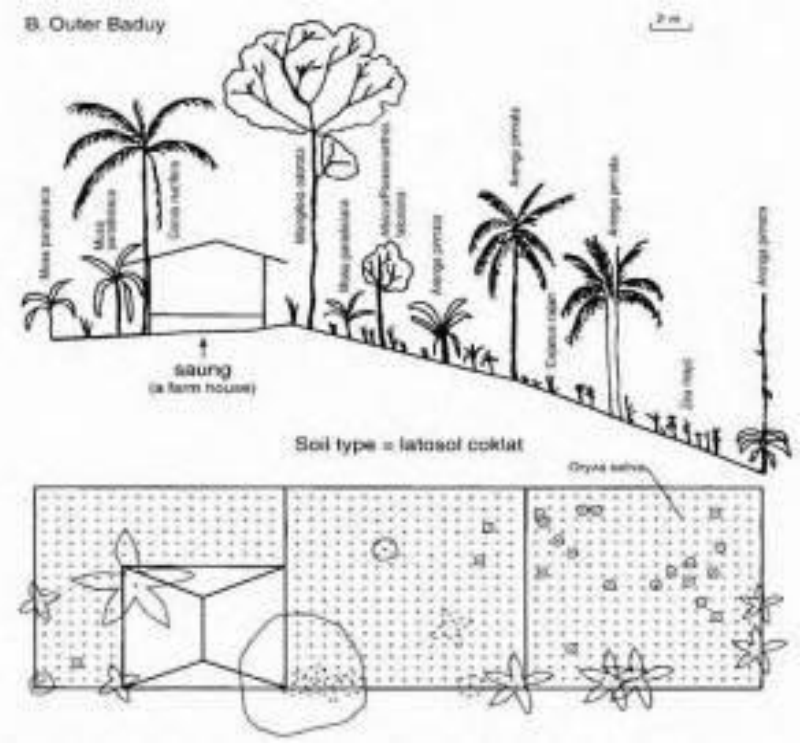

Figure 4. Vegetation structure of a typical swidden plot (huma) of Baduy Luar (Iskandar and Ellen 1999)

In addition, kawung trees that grow naturally in huma, reuma, leuweung lembur, and leuweung kolot are assisted mainly by careuh or luwak/common palm civet (P. hermaphroditusBesides loving eating birds, bird eggs, and other animals, this animal also likes to eat coffee berries and palm fruits (Subrata and Syahbudin 2016; Iskandar et al. 2019). These animals usually climb sugar palm trees, steal sap that the farmer is tapping, and eat ripe palm fruits. When the common palm civet poops, its feces contain palm seeds that can germinate and grow into young kawung. Similiar what they do in huma, the Outer Baduy people who find sugar palm seedlings in reuma and leuweung kolot also remove various terrestrial weeds, such as grasses and shrubs that grow around the kawung seedlings to prevent competition for nutrients and water in the soil. After the trees grow large, they are usually left to grow naturally, without further care.

Based on study on kawung in Baduy and other rural areas of Indonesia, it is generally accepted that in general kawung has not been intensively cultivated by the rural people. However, kawung grows naturally with the help of luwak (Febriyanti et al. 2017; Gunawan et al. 2018; Azhar et al. 2019; Harsoyo et al. 2020; Withaningsih et al. 2021).

\section{Uses and benefits of kawung}

There were 4 species of palm (Family Arecaceae) that have economic value in Outer Baduy, namely kawung ( $A$. pinnata), kiray (Metroxylon sagu Rottb.), kalapa (C. nucifera), and jambé (A. catechu). Among these four species, kawung has ecological, socio-economic, and cultural functions for the Baduy community (Table 3).

\section{Ecological function}

Kawung trees found in various biotopes in Outer Baduy play an important role in ecological functions, including soil protection against soil erosion and landslides control. This is because the kawung trees' roots have fibers that are very strong, deep, and scattered to protect soil erosion. In addition, kawung has the ability to secure water, so it can be planted in relatively dry-land areas and is important for water conservation (Iskandar 2014; Terryana et al. 2020).

In addition to soil protection function, kawung has an important role in plant pollination in Outer Baduy ecosystem because many bees, including odéng (Apis dorsata Fabricius, 1793) or nyiruan (Apis cerana indica Fabricius, 1798) have usually visited the inflorescences of kawung, and the high diversity of bee insects are found in the field-grown with kawung.

\section{Socio-cultural function}

Kawung has various socio-cultural functions for Outer Baduy community, including using kawung as raw materials of the traditional medicines, botanical pesticide, cigarette paper, roofing house and rice-barn (leuit), ropes, building material, firewood, traditional rituals, and folklore.

\section{Traditional medicinal ingredient}

Based on the tradition of the Outer Baduy community, various health disorders considered non-serious illnesses are usually treated by using various medicinal plants. For example, one species of plant commonly used as ingredients for treating the body that feels tired and has less energy is juice of kawung sugar (tuak kawung). To prepare this traditional medicine, the procedure is a very simple, namely tuak kawung is mixed with areca nut (A. catechu) and limus leaves (Mangifera foetida Lour.) then boiled in a pan on fire stove in the kitchen. Then, the boiled water can be drunk to recover the tired body (Iskandar and Iskandar 2005; Iskandar 2021).

\section{Botanical pesticide ingredient}

Unlike the Sundanese people in general, based on Baduy traditional law (pikukuh), Outer Baduy community is prohibited (tabu or teu wasa) to plant paddy in the irrigated paddy field (sawah). Conversely, practicing the swidden farming (ngahuma) is considered an obligation in the Baduy religion and can be considered their cultural identity. Since the land is considered sacred, some taboos, including hoeing the soil, applying modern rice seeds, employing inorganic fertilizers, and using synthetic pesticides are applied in the swidden system. Therefore, Outer Baduy community has been applying the organic farming and LEISA (Low External Inputs and Sustainable Agriculture) in their practice of swidden farming, recently promoted as new paradigm of Western knowledge after failure of the Green Revolution which emphasized the high inputs from outside of the village ecosystem and must be expensively purchased by farmers (Reijntjes et al. 1992). 
Table 3. Various ecological, and socio-economic and cultural functions of Arenga pinnata among Outer Baduy community

\begin{tabular}{|c|c|c|}
\hline Main function & Part of plant & Specific function \\
\hline \multirow[t]{3}{*}{ Ecological function } & Root & Soil erosion and landslide control \\
\hline & Bark & Pieces of midrib can be used as terraces in the huma for soil protection \\
\hline & Flower & Source of honey bee insects \\
\hline \multirow[t]{10}{*}{ Socio-cultural function } & Flower & Juice (tuak) is used as traditional medicine \\
\hline & Flower & Juice (tuak) is used as botanical pesticides \\
\hline & Young leaf & Young leaf is used as wrapping tobacco as cigarette paper \\
\hline & Fiber from the leaf & Raw material of house and rice barn (leuit) roof \\
\hline & Fiber from the leaf & Raw material of ropes \\
\hline & Trunk & Building material of house and rice barn (leuit) \\
\hline & Trunk & Raw material of stick \\
\hline & Leaflet midrib and young leafs & $\begin{array}{l}\text { Traditional ritual material of planting rice in swidden field (ngaseuk } \\
\text { huma) }\end{array}$ \\
\hline & Leaflet midrib & $\begin{array}{l}\text { Material for ritual of offerings to the ancestors after the rice harvest } \\
(\text { ngalaksa) }\end{array}$ \\
\hline & Kawung Plant & Folklore \\
\hline \multirow[t]{2}{*}{ Socio-economic function } & Inflorescences & Juice tapped for drinking (tuak) and material of botanical pesticide \\
\hline & Inflorescences & Juice tapped for making kawung palm sugar (gula kawung) \\
\hline
\end{tabular}

Traditionally, to eradicate various natural rice pests of the swidden faming systems, such as gaang (Gryllotalpa africana Palisot de Beauvois, 1805), kungkang (Leptocorisa acuta Thunberg, 1783), ganjur (Orseolia oryzae Wood-Mason, 1889), and kuuk (insect larvae of Holotrichia helleri Brsk.), botanical pesticides are commonly used by Outer Baduy people. The botanical pesticide ingredients consist of a mixture of kawung palm wine (tuak), cangkudu fruit (Momordica charantia L.), laja/galanga rhizome (Alpinia galanga (L.) Willd.), jeruk Bali peel (Citrus maxima (Burm.) Merr.), green coconut water (C. nucifera) and stove ashes (lebu hawu) which are usually applied to pest control in the swidden field (huma) that is being planted with rice (Iskandar 2012). Thus, the effect of the smell of these botanical pesticides can repel insect pests of rice. In other words, the botanical pesticides have been functioning as a repellent to drive insect pests away from the paddy crops (Reijntjes et al. 1992). Indeed, if insect pests directly contact the botanical pesticides, the pesticides can paralyze or kill these pests.

\section{Cigarette paper}

In the past, before kréték cigarettes intensively penetrated to many remote villages, Baduy community, particularly Outer Baduy people predominantly used the young leaves of kawung to make cigarette paper. Nowadays, however, the use of kawung leaves for smoking by the Outer Baduy has been decreasing because kréték cigarettes are easily bought in the small village shops.

Traditionally, to make cigarette paper, first, the young sugar palm leaves are harvested from the kawung. Second, each leaf is scraped by a knife until it is thin. Third, the young kawung palm leaves that have been thinned are placed on the house roof for drying with the sunshine. Fourth, the dried kawung palm leaves are cut into pieces about $10 \mathrm{~cm}$ long, almost the same size as a kréték cigarette. Fifth, when a person smokes, tobacco is rolled with the young kawung leaves, and the tip is burned, then inhaled by the smoker.

\section{Roofing material of house and rice barn (leuit)}

Traditionally, the Outer Baduy people still maintain traditional houses such as those of the Sundanese people in the past. The houses of the Outer Baduy community are very simple in the form of huts. Houses are built using various materials available in the local environment, such as wood, bamboo, kiray leaves (M. sagu), and kawung palm fibers/injuk kawung (A. pinnata). Wood is used for the pillars of the house. Bamboo is used for the walls and the floor of the house. Meanwhile, the kawung fibers and kiray leaves are mainly used for both the roof of house (hateup imah) and the roof of rice barn (hateup leuit) (Figure 5).

The kawung fibers are usually used as a coating for the leaves for the roof of the house and roof rice barn so that the leaves are stronger. This is possible because the rainfall does not pound directly on the kiray leaves on the roof of the house or the roof of the rice barn but first on the kawung fibers. Usually at a certain time, the kiray leaves along with the kawung palm fibers as the roof of the house and rice barn are replaced because the kiray leaves are damaged by exposure to rainwater and hot sun (Iskandar 2012).

\section{Rope materials of fastening}

Since the Outer Baduy predominantly uses various bioresources to fulfill the subsistence household daily needs, the kawung fibers are traditionally used as raw materials to make many products, including rope. In addition to kawung fiber, bamboo and hoe or rattans are commonly used as rope material in Outer Baduy. 

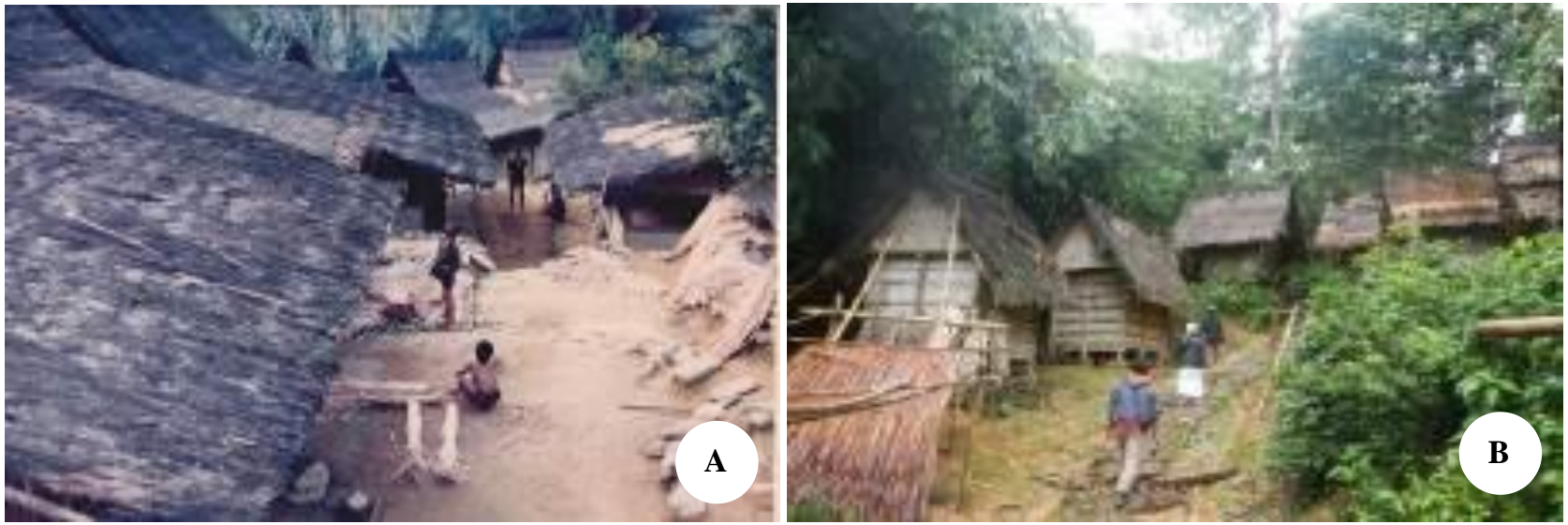

Figure 5. A. The traditional house, and B. rice barn (leuit) whose roofs are made of kiray leaves (Metroxylon sago Rttb.) and fiber of kawung

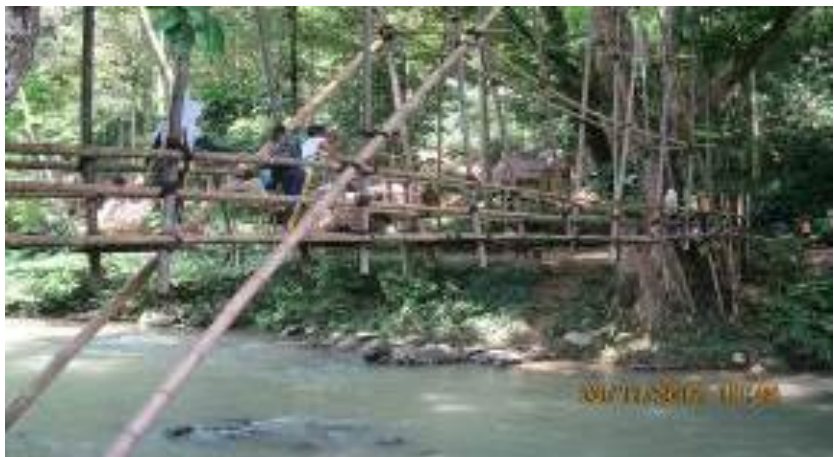

Figure 6. The traditional bamboo bridge of outer Baduy which uses kawung fibers for binding the bamboo

The Outer Baduy has a main river, the Ciujung River whose upstream is located in the traditional protected forest area of Cikeusik hamlet of Inner Baduy. Then, the river flows downstream through some Outer Baduy areas and non-Baduy areas. A bridge made of bamboo is built at the places where the Ciujung River of Outer Baduy must be crossed. To build the bamboo bridge they mainly use bamboo sticks, namely as a bridge or footing made of awi gedé (Gigantochloa verticillata (Wild.) Munro), and for the bridge support poles, and the handrails along the bridge they use awi hideung (Gigantochloa atroviolacea Widjaja). Meanwhile, to tie the bamboos to the bamboo bridge they use a rope of kawung fiber (Figure 6). Indeed, kawung fiber is often used as rope in Inner Based, because nail is prohibited to use in Inner Baduy.

\section{Building material}

Unlike in non-Baduy community, the kawung trees have never been cut down to make flour from their stem core in Outer Baduy. However, the non-productive and/or dead kawung trees, the logs are commonly used as various building materials, including houses and rice barns (leuit). Traditionally, the logs of kawung are usually used as a support under the floor of both the house (palupuh) and the rice barn.

\section{Traditional ritual material}

The Outer Baduy community in managing the swidden farming system (huma) uses the TEK and cosmos or belief. According to the cosmos of the Baduy people, they believe that the rice has a rice Goddess, called Nyi Pohaci (Dewi Sri in Javanese). Consequently, the huma farming systems are carefully managed and the local environment is maintained. To ensure the success of the rice planting, the Goddess of rice is highly respected, and almost every stage in the management of the huma farming systems, including planting and harvesting rice is usually accompanied by the traditional ceremonies (Iskandar and Iskandar 2017). For example, at the time of planting rice in Huma Serang (sacred swidden of Inner Baduy) and Huma Jaro Dangka (swidden of Informal leader-Jaro Dangka of Outer Baduy), a ceremony is usually conducted. The ceremony is carried out in a special place in the middle of the huma and for the ceremony, sawén is made from stem and midrib of immature leaves of kawung stuck in the ground with the supporting frame made of bamboo. The sawén place is considered sacred and used for ceremonies at the time of planting rice and harvesting huma rice.

At the ngalaksa ceremony it is also customary to use young leaves of kawung. Ngalaksa is a ceremony to make laksa from huma rice flour that has just been harvested from huma sérang in Inner Baduy and huma tauladan of Jaro Dangka in Outer Baduy.

At the ngalaksa ceremony of Outer Baduy, the Baduy men who take part in the ceremony make téké, anakanakan, and tutumbukan made of sticks and kawung leaves. Téké is a tool for wrapping laksa in the shape of a boat, made from kawung palm leaves whose ends are pinned by using a safety pin of the tiny bamboo stick. Next, some of the téké are joined together with bamboo skewers.

Tutumbukan as a symbol of man is made of kawung leaflet midrib that is split and the ends are shaped like a spear. The symbol of women is anak-anakan, made from palm leaves cut with a knife to form a person's body. Each family participates in the Ngalaksa ceremony to make a number of téké according to the number of individuals in the family. Meanwhile, the number of anak-anakan is based on the number of women and the number of 
tutumbakan according to the number of boys in each family. Then, téké, anak-anakan and tutumbakan from each family are gathered in a winnowing tray (nyiru) and offered to the Baduy ancestors by Jaro Dangka (informal leader), at a ceremony and worship of god by pronouncing Jaro Dangka in the forest area of the northern village where Jaro Dangka is settled (Iskandar 2012).

\section{Folklore}

In the Outer Baduy community, there are some stories related to kawung, such as the story of anak buncit (a child with a pot belly) and origin of kawung that can be tapped into sugar. In the story of anak buncit, it is told that a child with a pot belly who lost his mother was accompanied by his father looked for his mother to swidden field (huma). When anak buncit and his father arrived at the huma, they found a large animal that was suspected of being the killer of the anak buncit's mother. When they took shelter under a kawung tree, they heard a magical voice, which stated that anak buncit was welcome to kill the large animal with a spear made of awi tamiang pugur (Schizostachyum silicatum Widjaja). So, they stood on the kawung tree and speared the big animal to death with the tamiang pugur spears. Based on this story, kawung tree has never been cut down in Outer Baduy people (Iskandar et al. 2019).

The story of the origin of kawung which can be tapped in the Outer Baduy community is narrated by Iskandar (2012) as follows:

Once upon time, there were two children whose parents asked to guard the swiddens, when the paddy came to maturity. Many birds, called piit (Lonchura leucogastroides Horsfield \& Moore, 1856) ate paddy rice from the swidden. These birds were chased and perched on the inflorescence stalk of a sugar palm (leungeun kawung). Whenever these birds were chased, they always they came back. As a result, the children got angry (mamarahan) and the leungeun kawung was cut (dipagas) with chopping knife (golok). Juice came out and was tasted by the children. It was sweet. Therefore, the juice was collected in a bamboo internode (ruas awi). However, the fresh juice would not last for long and its taste became bitter and sour (haseum). The children then heard the voice of a kurah bird (Megalaema sp), which seemed to say kurah, kurah, kurah, kurah, kurah, repeated many times. They interpreted this to mean that that a bamboo internode should be cleaned with water first, called kungkurahan derived from kurah. Later, it was decided that before collecting the juice, the bamboo should be cleaned with water and smoked. Therefore, the juice can be kept by making it into palm sugar (gula kawung).

On the basis the folklore above, it can be perceived that kawung is not an introduced plant in Outer Baduy, but is considered a native plant and has become folklore material in the Baduy community.

\section{Socio-economic function: Making kawung palm sugar}

Although kawung is used for various uses, the main socio-economic function of kawung, especially the Outer Baduy, is to be tapped and made into sugar (gula kawung). Various materials, including sigay, paninggur, panyodék, nyiru, raru, cetakan gula-sugar-molded wood, malam odéng, kararas and daun salak are used to make the kawung sugar (Table 4).

Almost all materials used to make gula kawung are mainly harvested and obtained from the local ecosystems. For example, sigay, ruas, and nyiru are made from awi mayan (Gigantochloa robusta Kurz) and awi tali (Gigantochloa apus (Schult.f.) Kurz, respectively are harvested from various traditional agroforestry systems, including leuweung lembur, reuma and leuweung kolot. In addition, paninggur, panyodék, cétakan gula, and suluh are made from woody plant species, such as ki sabrang/sungkai (Peronema canescens Jacq), ki bangbara (Antidesma montanum Blume), onyam wood (Antidesma ghaesembilla Gaertn.), laban (Vitex pubescens Vahl), kopi (Coffea canephora Piere ex. A.Froehner), and tundun (Nephelium lappaceum L.) harvested from leuweung lembur, reuma and leuweung kolot. Meanwhile, sugar wrappers are made from dry banana leaves/kararas $(M$. $x$ paradisiaca $\mathrm{L})$ and dry salak leaves (Salacca zalacca (Gaertn.) Voss) usually harvested from huma, reuma and leuweung kolot. Thus, it can be inferred that plant biodiversity of Baduy ecosystems can play an important role in supporting the kawung sugar industry of Outer Baduy households. In other words, the various plant species that make up some Outer Baduy landscapes of Outer Baduy are not only important in providing ecosystem services, including producing oxygen $\left(\mathrm{O}_{2}\right)$, absorbing $\mathrm{CO}_{2}$, protecting the soil against erosion, and habitat of wild animals but also important for the socio-economic and cultural aspects of the Outer Baduy community, such as food, fruits, vegetables, medicinal, and ritual plants (Iskandar 2012).

\section{Making kawung sugar}

The Outer Baduy community commonly undertakes five stages to make kawung sugar, i.e., tapping the juice, boiling and evaporating the juice, coagulating the liquid, pouring the coagulated sugar into a wooden mold, and wrapping the kawung sugar (Iskandar 2012).

The first step is to select the productive palm trees grown in various land use types of Outer Baduy, including huma, reuma, leuweung lembur and leuweung kolot. The inflorescence stalks of selected productive kawung tree, which is about 5-10 years, are beaten with a big wood stick (paninggur) for 15-25 minutes, to obtain plenty of juice. This is traditionally accompanied by a special incantation. After about six weeks a very thin slice of inflorescence stalks are cut to test the production of juice. If plenty of juice comes out, the inflorescence stalk, about 25 centimeters length from the trunk, is cut with a machete (golok). The next day it is ready to be tapped, after which it is examined every few days.

Tapping is undertaken twice a day: in the morning, between 5.00 and 6.000 'clock and in the afternoon about 4.00-5.00 o'clock. In the morning, the tapper usually takes 2-3 bamboo internodes (ruas) with him. He climbs a kawung tree using a long bamboo ladder (sigay), in each internode a hole is made which can be used as a foot hold (Figure 7A). 
Table 4. Various materials that are commonly used in making kawung sugar among Outer Baduy community

\begin{tabular}{|c|c|c|}
\hline $\begin{array}{c}\text { Vernacular } \\
\text { name \& material }\end{array}$ & English common name & Function \\
\hline $\begin{array}{l}\text { Nira/peueut } \\
\text { kawung }\end{array}$ & Juice of kawung & $\begin{array}{l}\text { Raw material to make kawung sugar (gula } \\
\text { kawung) }\end{array}$ \\
\hline Ruas & $\begin{array}{l}\text { The bamboo internode (ruas) of awi mayan (Gigantochloa robusta } \\
\text { Kurz) }\end{array}$ & $\begin{array}{l}\text { For collecting kawung juice which is hung } \\
\text { over peduncle }\end{array}$ \\
\hline Sigay & $\begin{array}{l}\text { The long bamboo ladder made of awi mayan (Gigantochloa robusta } \\
\text { Kurz) or awi tali (Gigantochloa apus (Schult.f.) Kurz) and in each } \\
\text { node a hole is made to be used as foot hold }\end{array}$ & $\begin{array}{l}\text { For climbing a kawung tree to tap the } \\
\text { peduncle }\end{array}$ \\
\hline Paninggur & $\begin{array}{l}\text { The big wooden stick made of meuhmal (Litsea tomentosa Blume), } \\
\text { hearth wood of nangka (Artocarpus heterophyllus Lam.), hearth } \\
\text { wood of bungur (Lagerstroemia indica L.) }\end{array}$ & For beating the kawung peduncle \\
\hline Golok & Machete & For cutting the peduncle \\
\hline Kaén lamak & Cloth & $\begin{array}{l}\text { For preventing various dirt, bee insects, } \\
\text { rain water to falling into ruas that is hung } \\
\text { over the peduncle }\end{array}$ \\
\hline Kékéncéng & Big kettle & $\begin{array}{l}\text { For boiling the kawung juice to process of } \\
\text { sugar }\end{array}$ \\
\hline Panyodék & Wooden spoon & $\begin{array}{l}\text { For stirring the liquid that is being boiled } \\
\text { in the kékéncéng, and taking residues of } \\
\text { bees in the liquid }\end{array}$ \\
\hline Nyiru & $\begin{array}{l}\text { Flat woven bamboo made of awi tali (Gigantochloa apus (Schult.f.) } \\
\text { Kurz }\end{array}$ & $\begin{array}{l}\text { For covering the juice to prevent bees } \\
\text { insects being trapped in the liquid that is } \\
\text { placed in the kékéncéng }\end{array}$ \\
\hline Kuluwung & $\begin{array}{l}\text { Round woven bamboo made of awi tali (Gigantochloa apus } \\
\text { (Schult.f.) Kurz }\end{array}$ & $\begin{array}{l}\text { To prevent the liquid spilling over when it } \\
\text { is being boiled in the kékéncéng }\end{array}$ \\
\hline Raru & $\begin{array}{l}\text { Selected additives made of mardélan leaves (Macaranga tanarius } \\
\text { (L.) Müll.Arg., mara gedé fruits (Macaranga sp.), hiris leaves } \\
\text { (Cajanus cajan (L.) Huth), manggu leaves (Garcinia mangostana L.), } \\
\text { and areuy kawao (Millettia sericea (Vent.) Benth.) }\end{array}$ & $\begin{array}{l}\text { For maintaining the freshness of the juice } \\
\text { and good quality of sugar }\end{array}$ \\
\hline Cetakan gula & $\begin{array}{l}\text { Wooden mold which has } 6 \text { or } 7 \text { shapes made of half coconut shells } \\
\text { (batok) made of ki sabrang/sungkai (Peronema canescens Jacq), ki } \\
\text { bangbara (Antidesma montanum Blume), kayu onyam (Antidesma } \\
\text { ghaesembilla Gaertn.) }\end{array}$ & $\begin{array}{l}\text { To mold sugar when the boiling liquid has } \\
\text { coagulated in the kékéncéng }\end{array}$ \\
\hline Malam odéng & $\begin{array}{l}\text { Wax bees of odéng (Apis dorsata Fabricius, 1793) or nyiruan (Apis } \\
\text { cerana indica Fabricius, 1798) }\end{array}$ & $\begin{array}{l}\text { For preventing boiling over of the liquid } \\
\text { when it is being boiled in the kékéncéng }\end{array}$ \\
\hline $\begin{array}{l}\text { Kararas or daun } \\
\text { salak }\end{array}$ & $\begin{array}{l}\text { Dry banana leaves/kararas (Musa x paradisiaca L.) and dry salak } \\
\text { leaves (Salacca zalacca (Gaertn.) Voss) }\end{array}$ & $\begin{array}{l}\text { For wrapping the kawung sugar (gula } \\
\text { kawung) }\end{array}$ \\
\hline Suluh & $\begin{array}{l}\text { Fire wood made of various trees, such as laban (Vitex pubescens } \\
\text { Vahl), kopi (Coffea canephora Piere ex. A.Froehner), tundun } \\
\text { (Nephelium lappaceum L.). }\end{array}$ & $\begin{array}{l}\text { As fire wood burned in the stove (gonggo) } \\
\text { for boiling juice or liquid in the kékéncéng } \\
\text { to processing kawung palm sugar }\end{array}$ \\
\hline Gonggo & $\begin{array}{l}\text { A stove made by digging a pit about } 1 \text { meter deep and } 0.5 \text { meters } \\
\text { wide. The walls of the stove are cemented with a semi clay soil and } \\
\text { mixed with palm fiber. Three holes are made on the upper parts. }\end{array}$ & $\begin{array}{l}\text { For firing the wood in the process of } \\
\text { making kawung palm sugar }\end{array}$ \\
\hline
\end{tabular}
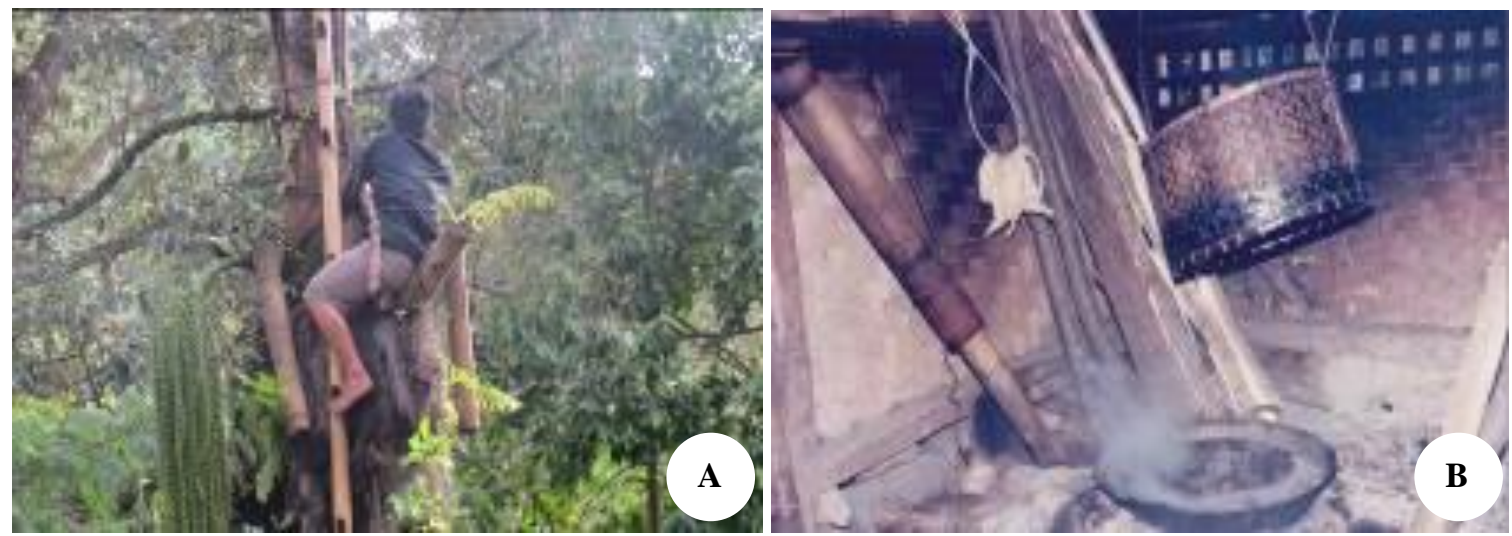

Figure 7. A. The tapper of Outer Baduy man is climbing using sigay to tape the peduncle of kawung, and B. The juice is being boiled for shot time on a stove. The ruas bambu are washed with clear water and smoked by placing them upside down on a small bamboo stick above a stope 
Peduncle is beaten with the paninggur a few times and very thin slice is cut from the peduncle. Juice is collected in a bamboo internode (ruas), hung over the peduncle, and to prevent dirt falling into the ruas, the peduncle and upper ruas are covered with a cloth. Common sources of contamination are kawung flowers (kembang kawung), bees, and water, particularly during the rainy season.

In the afternoon the ruas are removed. The peduncle is beaten and a very thin slice is cut, the resulting juice is collected in a new ruas. The full ruas are carried to a farm shelter located near the hamlet, where the juice is poured into a big kettle (kékéncéng). To prevent fermentation, the juice is boiled for a short time on a stove called tungku gonggo. The ruas are washed with clear water and smoked (dipuput), by placing them upside down on a small bamboo stick above a stove (Figure 7B). Before the shelter is left, the rest of the fire wood in the stove is removed and the kettle is covered with a winnowing tray (nyiru) to prevent insects being trapped in the liquid. The smoked ruas are taken from the stove and hung on the wall.

Second, after collection of juice for a few days, the kékéncéng is full of liquid. The liquid is now ready to be processed through boiling and evaporation. The juice is boiled for several hours (nyaahkeun wédang). The liquid is sometimes stirred during boiling, and residues such as bees are removed with a wooden spoon. To prevent the liquid from spilling over, a kékéncéng is covered with a kuluwung made of woven bamboo and some wax of odéng ( $A$. dorsata) or nyiruan (A. indica) is put in the liquid, now called mépés, to prevent from boiling over. To maintain the freshness of the juice and to produce good quality sugar, selected additives (raru), such as mardelan leaves (Macaranga tanarius (L.) Müll.Arg.), mara gedé fruit (Macaranga sp.), hiris leaves C. cajan, manggu leaves (Garcinia mangostana L.), and areuy kawao, a kind of vine (Millettia sericea (Vent.) Benth.) are put in the liquid.

Third, if the liquid has coagulated, it is called immature sugar (gula ngora). In this case it must be stirred vigorously and removed from the heat. A wooden spoon (panyodék) and iron spoon (susuk) are used to stir the liquid.

Forth, as soon as the liquid coagulates further, it turns dark red and begins to settle, and it is called gula kolot (mature sugar), and at this point the sugar is poured into a wooden mold which has 6 or 7 shapes made from half coconut shells (Figure 6). The resulting hard block sugar is therefore called sabatok (a half of coconut shell), and a pair of sabatok called sahulu (a head), while every ten batok is called a sakojor.

Fifth, after drying, the sugar is taken out of the wooden mold, and collected in nyiru and brought home. At night, the sugar is wrapped in dry banana (M. $x$ paradisiaca) or salak ( $S$. zalacca leaves (Figure 8). This sugar is now ready to be sold and some are used for household purposes. In some cases, sugar blocks are stored on a dry shelf above the stove (parako). When a sufficient number have accumulated they are taken, wrapped, and sold to middlemen in the same or other hamlets.

\section{Kawung sugar production}

Production of the kawung sugar (gula kawung) is determined by many factors, including the production of the juice of each peduncle, the number of peduncles for each tree, and number of the productive trees that can be tapped.

According to informants, each family of Outer Baduy have 3-6 kawung trees and each tree normally owns 6-10 stalks. If three peduncles can be tapped every day, so over three days they yield about 10-20 batok or 5-10 hulu, or 1-2 kojor of sugar. Normally one tree has 4-8 peduncles (leungeun kawung) and one in every 3 peduncles can be tapped to 10 hulu in each tree days, giving an average of 100 hulu each month. In other words, sugar production each month averages 10 times the production of one session (nyaahkeun), or $10 \times 10$ hulu $=100$ hulu, which is equivalent to 25,000-30,000 rupiah or at least 100-125 liter of rice in 1985. In one year, representing about 6-8 months of active tapping, or from 4-8 peduncles only, with one peduncle is assumed to produce juice, 6-8 x 100 hulu or the equivalent of 600-800 hulu x (250-300 rupiah) $=150,000$ 240,000 rupiah (600-800 liter) are produced in 1985 . While in 2021, production of 600-800 hulu is equivalent to 5,700,000-8,000,000 rupiah, and price of gula kawung increased over time (Table 5).
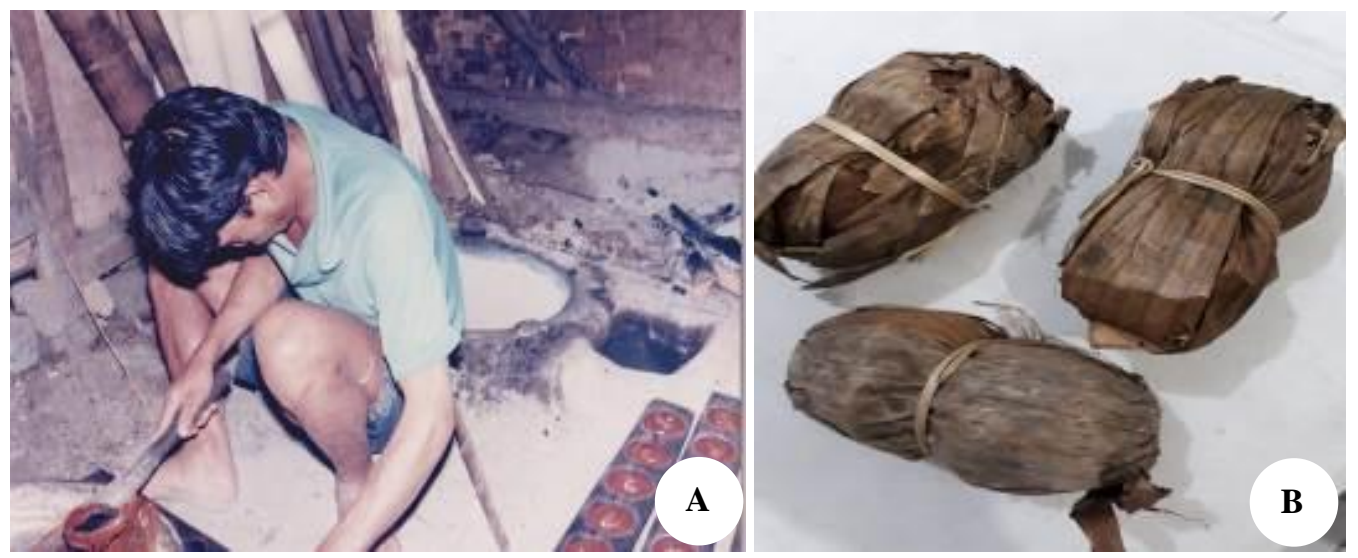

Figure 8. A. The coagulate is being poured into a wooden mold, and B. Kawung sugars are wrapped by the dry banana leaves 
Table 5. Price of kawung sugar in Outer Baduy in 1985-2021

\begin{tabular}{llll}
\hline Year*) & Kawung sugar price & Price of rice & Ratio of kawung sugar price to rice price \\
\hline 1985 & $250-300 /$ hulu & $200-250 /$ liter & $0.80-0.83$ \\
1995 & $400-500 /$ hulu & $300-350 /$ liter & $0.75-0.70$ \\
2004 & $2,000-2,5000 /$ hulu & $2,000-2,500 /$ liter & $1.00-1.00$ \\
2015 & $6,500-7,000 /$ hulu & $8,000-8,500$ & $1,23-1,21$ \\
2017 & $6,500-7,500 /$ hulu & $8,000-8,500 /$ liter & $1,23-1.13$ \\
2021 & $9,500-10,000 /$ hulu & $7,500-8,000 /$ liter & $0,78-0,8$ \\
\hline
\end{tabular}

Note: $*$ The field note; 1 USD in 2021= 14.500 Indonesian rupiah $(\mathrm{Rp})$

It can be seen from Table 5 that the price of kawung sugar has increased over time. In 1985 the price of kawung sugar was Rp 250-Rp 300/hulu, while in 2021 the price of kawung sugar increased to $\mathrm{Rp} 9,500-10,000 / \mathrm{hulu}$. According to the tradition, the swidden rice is strongly prohibited to sell; as a result, the non-rice productions, including trading the kawung sugar the Outer Baduy have been able to maintain the integrity of their swidden system which is the central part of their cultural identity (Iskandar 2012). The sugar palm has been used based on moral versus economic interest. In terms of morals, the sugar palm has been used for socio-cultural aspects, including rituals, traditional medicine, and botanical pesticides in the swidden farming. The palm sugar has been predominantly traded for economic interest to obtain cash income from the Outer Baduy households.

\section{Traditional conservation}

Kawung grows in mixture with various woody plants of different height and light requirement in various traditional agroforestry systems of Outer Baduy, including huma, reuma, and leuweung lembur, resulting in vegetation with a complex vertical structure. Therefore, the traditional agroforestry of Outer Baduy resembles a forest with its natural ecological and socioeconomic and cultural functions. The natural ecological functions of forest consist of hydrologic and soil erosion control, microclimatic effects, carbon storage, animal habitat, and biodiversity conservation. Its economic functions include producing fruits, vegetables, building materials, and rituals for subsistence and some surpluses for trading to make money.

The traditional agroforestry systems are prohibited from converting to monoculture commercial garden systems. Therefore, both ecological, socio-economic, and cultural functions of Outer Baduy have been maintained over time. Among various plant species, kawung can be used sustainably by the Baduy community because the use is based on traditional ecological knowledge and belief or cosmos (Van Der Broek et al. 2011; Iskandar 2018). According to the belief, the kawung is prohibited to cut. In addition, the common-palm civet- luwak ( $P$. hermaphroditus), as an animal for assisting distribution and natural regenerations of the kawung in various traditional agroforestry has been rarely hunted. Accordingly, the population of luwak has not decreased, and has played an important role in maintaining natural regeneration of kawung in Outer Baduy ecosystem. Moreover, the kawung can be conserved in Outer Baduy.

Other factors leading to sustainable use of kawung are the prohibition of cutting the kawung trees for making flour, and using kawung seeds to make sweetmeat (kolang kaling). Conversely, in non-Baduy, the Sundanese villagers of West Java and Banten have commonly cut down kawung trees to make flour, and used kawung fruit as sweetmeat or kolang kaling (Febriyanti et al. 2017; Iskandar 2018; Withaningsih et al. 2019.

It can be seen that the combination of biophysical and socio-cultural factors, which together determine an individual's decision-making environment, lead to the sustainable management and use of kawung by Outer Baduy and this plant continues providing ecological and socio-economic and cultural functions (Bélair et al. 2010). In other words, the actions of the Outer Baduy people (praxis) in treating kawung and their agroforestry systems are strongly influenced by their perceptions and knowledge (corpus) of kawung and the traditional agroforestry by forming a complex system of corpus-cosmos-praxis (Berkes 2012; Iskandar 2018), and the diversity and culture of Baduy have formed special the biocultural system (Barthel et al. 2013; Maffi and Dilts 2014; Seele et al. 2019). In addition, since kawung has ecological, socioeconomic and cultural functions, this species can also be considered the Outer Baduy community (Platten and Henfrey 2009; Coe and Gaoue 2020). It can be concluded that the Outer Baduy people have used their rich traditional ecological knowledge to manage kawung on a sustainable basis which provides ecological, socio-economic and cultural functions.

\section{ACKNOWLEDGEMENTS}

This research would not have been possible with supporting the ALG (Academic Leadership Grant) program of Padjadjaran University, so we thank the rector of Padjadjaran University who financial support of this research. We also like to thank the formal village leader and his staff of Kanekes Village, informal leaders of hamlet of Kaduketug, Babakan Marengo, and Gajeboh, and all informants of Outer Baduy people who patiently and generously shared their knowledge with us. 


\section{REFERENCES}

Albuquerque UP, Cruz da Cunha LVF, de Lucena RFP, Alves RRN 2014. Methods and Techniques in Ethnobiology and Ethnoecology. Humana Press, New York. DOI: 10.1007/978-1-4614-8636-7.

Amrul HMZN. 2018. The use of sugar palm trees in the ceremony Sipaha Lima of Parmalim Communities. BioLink 4 (2): 170-174. [Indonesian]

Anwar 2018. Nilai Manfaat Tanaman Aren (Arenga Pinnata) di Desa Taulan, Kecamatan Cendana, Kabupaten Enrekang. [Hon. Thesis]. Fakultas Pertanian Universitas Muhammadiyah Makassar, Makasar. [Indonesian]

Azhar I, Risnasari I, Serena MF, Riswan. 2019. The utilization of sugar palm (Arenga pinnata) by the people around Batang Gadis National Park Area. IOP Conf Ser Earth Environ Sci 305: 1-8. DOI 10.1088/1755-1315/305/1/012016.

Backer CA, Bakhuizen van den Brink JrRC. 1968. Flora of Java Vol.1-3 Wolters-Noordhoff NV, Groningen.

Barthel S, Crumley CL, Svedin U. 2013. Biocultural refugia: Combating the erosion of diversity in landscapes of food production. Ecol Soc 18 (4): 1-15. DOI: 10.5751/ES-06207-180471.

Bélair C, Ichikawa K, Wong BYL, Mulongoy KJ. 2010. Sustainable Use of Biological Diversity in Socio-Ecological Production Landscapes. Background to the 'Satoyama Initiative for the Benefit of Biodiversity and Human Well-being.' Secretariat of the Convention on Biological Diversity, Montreal.

Berkes F. 2012. Sacred Ecology. Third Edition. Routledge, New York and London. DOI: 10.4324/9780203123843.

Coe MA, Gaoue G. 2020. Cultural keystone species revisited: Are we asking the right questions? J Ethnobiol Ethnomed 16 (70): 1-11. DOI 10.1186/13002-020-00422-z

Ellen R. 2006. Local knowledge and management of sago plam (Metroxylon sago Rottboell) diversity in South Central Seram Maluku, Easteren Indonesia. J Ethnobiol 26 (2): 258-298. DOI: 10.2993/0278-0771(2006)26[258:LKAMOS]2.0.CO;2.

Erawan TS, Alillah AN, Iskandar J. 2018. Ethnobotany of traditional rituals in the Karangwangi Village, Cianjur District, West Java. Asian J Ethnobiol 1 (2): 53-60. DOI: 10.13057/asianjethnobiol/y010201.

Fatriani, Sunardi, Prayudi F. 2012. Effect of age tree palm (Arenga pinnata Merr) against production of nira in Pulantan Village, Awayan District, Balangan Regency, South Kalimantan Province. J Hutan Tropis 13 (1): 11-17. [Indonesian]

Febriyanti N, Hikmat A, Zuhud EAM. 2017. The ethnobotany and potential of sugar palm (Arengga pinnata Merr) on Kasepuhan Pasir Eurih Community, Sindanglaya Village, Lebak Regency, Banten. Media Konservasi 22 (2): 171-180. [Indonesian]

Franco FM, Hidayati S, Ghani BAA, Ranaivo-Malancon B. 2015 Ethnotaxonomic systems can reflect the vitality status of indigenous languages and traditional knowledge. Indian J Tradit Knowledge 14 (2): $175-182$

Garibaldi A, Turner N. 2004. Cultural keystone species: Implications for ecological conservation and restoration. Ecol Soc 9 (3): 1-18. DOI: 10.5751/ES-00669-090301.

Gunawan R, Ramadhan UG, Iskandar J, Partasasmita R. 2018. Loca knowledge of utilization and management of sugar palm (Arenga pinnata) among Cipanggulaan people of Karyamukti (Cianjur, West Java, Indonesia). Biodiversitas 19 (1): 93-105. DOI: 10.13057/biodiv/d190115.

Harsoyo A, Zuhud IAM, Hikmat A, Sunkar A, Darusman D. 2020. Ecological Aspect and Regeneration of Sugar Palm in the Sasak Community Gardens of Kekakit Village, West Nustengara, Indonesia. J Management Hutan Tropica 26 (1): 1-12. DOI: 10.7226/jtfm.26.1.1. [Indonesian]

Heyne K. 1987. Useful Plant of Indonesia. Badan Litbang Kehutanan, Jakarta, Indonesia. [Indonesian]

Hidayati S, Suansa NI, Samin, Franco FM. 2017. Using ethnotaxonomy to access traditional knowledge and language vitality: A case study with the Urang Kanekes (Baduy) of Banten, Indonesia. Indian J Tradit Knowledge 16 (4): 576-582.

Iskandar J and Iskandar BS. 2005. Alternative Medicecine of Baduy Version. Humaniora, Bandung [Indonesian].

Iskandar J 2012. Swidden Ecology of Baduy People: Forest Management Based on Culture and Sustainable System. Penerbit PT Alumni, Bandung. [Indonesian]

Iskandar J. 2014. Human and Environment with Various Changes. Graha Ilmu, Yogyakarta. [Indonesian]

Iskandar J. 2018. Ethnobiology, Ethnoecology and Sustainable Development. Plantaxia, Yogyakarta. [Indonesian]
Iskandar J. 2021. Pandemics and sustainable human nature relations: A case study in Baduy Community, South Banten Indonesia. E3S Web Conf 249: 1-17. DOI: 101051/e3sconf/202124901001.

Iskandar BS, Iskandar J, Irawan B, Suroso, Partasasmita R. 2019. The development of coffee cultivation in the traditional agroforestry of mixed-garden (Dukuh Lembur) to provide socio-economic benefits for the Baduy Community, South Banten, Indonesia. Biodiversitas 20 (10): 2958-2969. DOI: 10.13057/biodiv/d201026.

Iskandar J, Iskandar BS. 2017. Various plants of traditional rituals: Ethnobotanical research among the Baduy Community. Biosaintifica 9 (1): 114-125. DOI: 10.15294/biosaintifika.v9i1.8117.

Iskandar J, Ellen R. 1999. In situ conservation of rice landraces among the Baduy of West Java. J Ethnobiol 19 (1): 97-125.

Kurniawan T, Jayanudin, Kustiningsih I, Firdaus MA. 2018. Palm sap sources, characteristics, and utilization in Indonesia. J Food Nutr Res 6 (9): 590-596. DOI: 10.12691/jfnr-6-9-8.

Maffi L, Dilts O. 2014. Biocultural Diversity Toolkit: Introduction to Biocultural Diversity. Terralingua, Salt Spring Island, British Columbia.

Mogea J, Seibert B, Smith W. 1991. Multipurpose palms: The sugar palm (Arenga pinnata (Wurmb) Merr). Agrofor Syst 13 (2): 111-129. DOI: 10.1007/BF00140236.

Newing H, Eagle CM, Puri RK, Watson CW. 2011. Conducting Research in Conservation: Social Science Methods and Practice. Routledge, London and New York. DOI: 10.4324/9780203846452.

Platten S, Henfrey T. 2009. The cultural keystone species concept: Insight from ecological anthropology. Hum Ecol 37 (4): 491-500. DOI: 10.1007/s10745-009-9237-2.

Rapini A. 2014. Introduction to botanical taxonomy. In: Albuquerque UP, Cruz da Cunha LVF, de Lucena RFP, Alves RRN (eds.). Methods and Techniques in Ethnobiology and Ethnoecology. Humana Press, New York. DOI: 10.1007/978-1-4614-8636-7_9.

Ratnani DAS, Junitha IK, Kriswiyanti E, Dhana IN. 2021. The ethnobotany of Ngusaba ceremonial plant utilization by Tenganan Pegringsingan community in Karangasem, Bali, Indonesia. Biodiversitas 22 (4): 2078-2087. DOI: 10.13057/biodiv/d220457.

Reijntjes C, Haverkort B, and Waters-Bayer A. 1992. Farming for The Future: An Introduction to Low-External-Input and Sustainable Agriculture. MacMillan Press Ltd, London.

Seele BC, Esler KJ, Cunningham AB. 2019. Biocultural diversity: A Mongolian case study. Ecol Soc 24 (4): 1-23. DOI: 10.5751/ES-11207-24027.

Soemarwoto R, Iskandar J. 2021. Plant knowledge richness in the Sundanese upland village: A case study in Sindangsari, West Java, Indonesia. Biodiversitas 22: 3722-3735. DOI: 10.13057/biodiv/d220916

Statistical Data of Kanekes Village. 2018. The Population number of Kanekes Village. Kanekes Village Office Data, Banten. [Indonesian].

Subrata SA, Syahbudin A. 2016. Common palm civet as a potential seed disperser of important plant species in Java. AIP Conf Proc 1744: 1-4. DOI: $10.1063 / 1.4953527$

Sujarwo W, Caneva G, Zuccarello V. 2020. Patterns of plant use in offerings in Bali (Indonesia). Acta Botanica Brasilica 34 (1): 40-53. DOI: 10.1590/0102-33602019abb0110.

Surya E, Ridhwan M, Armi, Jailani, Samsiar. 2018. Sugar palm tree (Arenga pinnata Merr) conservation in the utilization of sugar palm tapped for enhancing community economics in Padang Village, Terbangun Sub-district, Gayo Lues District. Bionatural: J Ilmiah Pendidikan Biologi 5 (2): 34-45. [Indonesian]

Terryana RT, Nugroho K, Lestari P. 2020. Genetic diversity of sugar palm population from Cianjur and Banten by Simple Sequence Repeat (SSR) Marker. IOP Conf Ser Earth Environ Sci 418: 1-10. DOI: 10.1088/1755-1315/418/1/01/012038.

Van Der Broek I, Reyes-Garcia V, de Alburque UP, Bussmann R, Pieroni A. 2011. Local knowledge: Who cares? J Ethnobiol Ethnomed 7 (35): 1-7. DOI: $10.1186 / 1746-4269-7-35$.

Withaningsih S, Parikesit, Iskandar J, Putri R. 2019. Socio-ecological perspective of local bio-resources based production system of palm sugar and palm flour from aren (Arenga pinnata): Case study of Sukaresmi Village, West Bandung, Indonesia. Biodiversitas 20 (7): 1990-1997. DOI: 10.13057/biodiv/d200727.

Withaningsih S, Pariksesit, Nursislamidi H. 2021. Management strategies of palm sugar (Arenga pinnata) production on extreme landscapes of Rongga, West Bandung Regency. Intl J Conserv Sci 12 (2): 625-640.

Zuhud EAM, Almanar P, Zuraida, Hidayati S. 2020. Potency and conservation of aren (Arenga pinnata (Wurm) Merr.) in Meru Betiri National Park, East Java-Indonesia. J Manajemen Hutan Tropika 26 (3): 212-221. DOI: 10.7226/jtfm.26.3.212. [Indonesian] 